\begin{tabular}{|l|l|l||}
\hline \multicolumn{2}{|c|}{ PublisherInfo } \\
\hline \hline PublisherName & $:$ & BioMed Central \\
\hline \hline PublisherLocation & $:$ & London \\
\hline \hline PublisherImprintName & $:$ & BioMed Central \\
\hline \hline
\end{tabular}

\title{
Y-chromosome multicopy genes
}

\begin{tabular}{|l|l|l||}
\hline \multicolumn{2}{|c|}{ ArticleInfo } \\
\hline \hline ArticleID & $:$ & 3930 \\
\hline \hline ArticleDOI & $:$ & $10.1186 /$ gb-2001-2-8-reports0023 \\
\hline \hline ArticleCitationID & $:$ & reports0023 \\
\hline \hline ArticleSequenceNumber & $:$ & 21 \\
\hline \hline ArticleCategory & $:$ & Paper report \\
\hline \hline ArticleFirstPage & $:$ & 1 \\
\hline \hline ArticleLastPage & $:$ & 3 \\
\hline \hline & & RegistrationDate : 2001-6-20 \\
ArticleHistory & $:$ & Received \\
\hline ArticleCopyright & $:$ & BioMed Central Ltd2001 \\
\hline \hline ArticleGrants & $:$ & \\
\hline \hline
\end{tabular}




\begin{tabular}{|l|l|l||}
\hline ArticleContext & $:$ & 130592288 \\
\hline
\end{tabular}

\section{S Subramanian}

\section{Abstract}

A multiple copy gene family on the human Y chromosome has been shown to be transcribed but not translated.

\section{Significance and context}

The mammalian Y chromosome carries genes specializing in sex determination and spermatogenesis; the human $\mathrm{Y}$ chromosome is about 59 megabases $(\mathrm{Mb})$, and carries an estimated 100 genes. At present, about 47 Y-linked genes and pseudogenes have been identified and the protein sequences encoded by about 20 of these have been submitted to the SWISS-PROT protein database. Despite its pairing with the $\mathrm{X}$ chromosome, most of the $\mathrm{Y}$ chromosome does not recombine. The non-recombining region, which in humans constitutes about $95 \%$ of the $\mathrm{Y}$ chromosome, does not exchange genetic material with the $\mathrm{X}$ chromosome except in the pseudoautosomal regions. Mutations that appear on the Y chromosome therefore accumulate and are not repaired. Several genes that are involved in spermatogenesis such as $R B M Y, D A Z$ and TSPY are present in multiple copies on the Y chromosome. Given that not all cases of human idiopathic infertility are explained by deletion of known Y-linked or autosomal genes, it is likely that many other Y-linked genes with roles in male fertility remain to be discovered. Makrinou et al. have identified a Y-linked gene family whose transcripts do not contain open reading frames (ORFs). Although Y-linked genes without ORFs have been identified previously (TTY1 and TTY2, for example), this is the first entire gene family to be found whose members contain no ORFs.

\section{Key results}

Makrinou and colleagues screened a testis cDNA library with human Y-chromosome cosmid clones to identify Y-linked, testis-expressed genes. After eliminating all the repetitive or vector material, the remaining 79 clones were sequenced. They identified 19 cDNAs that showed homology with the TTY2 gene and suggested that TTY2 is part of a large gene family. Screening a panel of Y-linked cosmids revealed that the TTY2 gene family includes at least 26 members organized in 14 subfamilies. Further investigation revealed that TTY2 genes are arranged in tandemly arrayed clusters on both arms of the Y chromosome, and each gene comprises a series of tandemly arranged repeats. Fluorescence in situ hybridization (FISH) studies on metaphase chromosomes of human, chimpanzee and gorilla revealed that TTY2 sequences are present at distinct locations on the short arm and the long arms of the Y 
chromosome. Expression profiling of these genes revealed that they are expressed in adult testis and kidney. The expression of TTY2 transcripts in testis and kidney is not a surprise, as these two organs are developmentally related. None of the genes investigated in detail contains an ORF. The authors conclude that the TTY2 gene family is composed of multiple copies, some of which may function as non-coding RNA transcripts and some may be pseudogenes.

\title{
Reporter's comments
}

As the Y chromosome has evolved a mechanism that supports the multiplication of its genes to protect them from the deleterious effects of non-recombination, it can be argued that some of the transcripts of the TTY2 gene family may be non-coding RNA genes, or non-functional degenerating copies of other genes on the Y chromosome. Finding the function of these non-coding RNA genes will be challenging. Studying the secondary structure of these transcripts may shed some light on their cellular role. The results presented by Makrinou et al. support the view that Y chromosome sequences are degenerating due to lack of recombination and encourages us to think about the evolution of the $\mathrm{Y}$ chromosome.If all these genes are shown to be non-functional and degenerating due to the accumulation of mutations, it may be possible to calculate the rate of overall degeneration, and therefore lifespan, of this unique chromosome. But if these transcripts are functioning as regulatory RNA genes then they are likely to be retained over evolutionary time.

\section{Table of links}

\author{
Genome Research
}

\section{References}

1. Makrinou E, Fox M, Lovett M, Haworth K, Cameron JM, Taylor K, Edwards YH: TTY2:a multicopy Y-linked gene family. Genome Res. 2001, 11: 935-945. 1088-9051 